\title{
A paróquia na mudança de época: rede de comunidades na era da informação
}

\author{
Orientador: Abimar Oliveira de Moraes \\ Mestrando: Emerson Marcelo Ruiz \\ Área de Concentração: Teologia Sistemático-Pastoral
}

Linha de Pesquisa: Religião e Modernidade

Esta investigação aborda a paróquia católica na mudança de época, a partir das teorias de Manuel Castells. O início do milênio testemunha, de um lado, inédito interesse pastoral pela paróquia. De outro lado, temos muitos estudos multidisciplinares sobre mudança de época. Esta dissertação articula estas duas realidades. Ela analisa a paróquia a partir do seu nascimento no séc. IV. Acompanha sua evolução histórica até o Concílio de Trento, passando pelas novas configurações paroquiais do Vaticano II e do magistério Latino-Americano. Para abordar a mudança de época, esta pesquisa utiliza a teoria sociológica de Manuel Castells. A era da informação é a era das redes. A paróquia poderá aclimatar-se na medida em que compreender os novos significados desta nova estação histórica, tais como a nova territorialidade, dinâmica das redes e interatividade.

Palavras-chave: Paróquia. Manuel Castells. Comunidade Cristã. 